\title{
Enterprises Financial Performance in a Globalized World
}

\author{
Ivana Podhorska ${ }^{1, *}$ and Anna Siekelova ${ }^{2}$ \\ ${ }^{1}$ University of Zilina, Department of Economics, Univerzitna 1, 01026 Zilina, Slovak Republic \\ ${ }^{2}$ University of Zilina, Department of Economics, Univerzitna 1, 01026 Zilina, Slovak Republic
}

\begin{abstract}
World globalization has a significant impact on the financial performance and financial health of enterprises. The aim of the paper is to analyse and compare the financial performance of selected enterprises under the conditions of globalization. Paper will work with six selected enterprises from the IT sector, which represents one of the fastest growing sectors in the globalized world. Each of them will be from the Slovak Republic. As input data will be used their financial statements during years 2015-2018. These data will be obtained from the Amadeus database - a database of comparable financial information for public and private companies across Europe. The methods of financial-economic analysis will be used to analyse these data. Especially, the paper will be work with selected financial ratios from analysing of liquidity, profitability, indebtedness, and activity. The theoretical part of the paper will contain a literature review and historical development of financial performance assessment and theoretical aspects of enterprise financial performance. The practical part will contain the application of selected methods of financial-economic analysis in the database of enterprises. Paper findings brings evaluation of financial performance of enterprises in IT sector under the conditions of globalized world.
\end{abstract}

\section{Introduction}

In 1494, the monk Luca Pacioli of Florence formalized the first accounting system in which he described the meaning of the books. His accounts included accounts payable, capital, deposit, loan, but also receivables and inventories. [1, 2, 3] Further development of this field was recorded in the years 1900 - 1919 when several ratios were created. Also in 1919, Alexander Wall created the first major financial plan. In 1935, Winker and Smith compared the ratios on a sample of businesses. Roy A. Foulke and Paul J. Fitzpatrick are among the others who dealt with ratios. [2, 4, 5, 6] There are few records of the overall development of the financial analysis. Authors dealing with this topic include I. Brown, J. Horrigan, V. Kovalev, and T. Salmi. In Slovakia, several authors are currently dealing with financial analysis. $[3,7,8,9]$

In 2009, professor Cisko described the methods of performing the analysis and later, in 2016, together with professor Klieštik, he devoted himself to financial analysis in much more detail. They described methods of predicting the financial situation and also analyzed

\footnotetext{
*Corresponding author: ivana.podhorska@fpedas.uniza.sk
} 
the relationships between financial indicators. In this thesis we draw a lot of information from the book by Karol Zalai. In his book, he devoted himself deeply to financial analysis, which, in his view, assesses the economic activity of an undertaking on the basis of the factors which caused it. [1, 2, 9, 10, 11, 12]

Bartosova and Kral (2016) state that the basic impulse for the financial and economic analysis of the company is the knowledge and evaluation of its financial health. The impulse results from the primary function of financial-economic analysis, which is to provide a comprehensive view of the financial situation of the company. [2, 11, 13, 14] Financial-economic analysis brings together the evaluation of the company's past, present and effort to predict the financial management and financial stability of the company in the future. In the words of the authors: "it is very difficult to imagine a quality manager of a company who has no idea how profitable his company is, what is the average maturity of receivables, what added value is created by his employees, etc." [12, 15, 16]

Sponte (2018) argue that what the resulting financial-economic analysis of an enterprise will look like (content, scope, methods used, etc.) ultimately depends on who it is addressed for, the size of the enterprise, the industry classification, and so on. In order to achieve success and relevance of the results of the financial-economic analysis, high-quality input data must be used for its implementation. The primary data base includes the financial statements of the financial accounting of the enterprise, However, there are other sources of data for financial-economic analysis, usually having a supportive, respectively. secondary character (eg interim or annual company reports, company payroll reports, etc.). [16, 17, 18] In order to gain a better picture of the financial-economic position of any enterprise and to increase the informative power of the results of the financial-economic analysis, it is desirable that the selected findings be compared with the median values for the sector concerned. $[6,19,20]$

The aim of the paper is to analyse and compare the financial performance of selected enterprises under the conditions of globalization. Paper will work with six selected enterprises from the IT sector, which represents one of the fastest growing sectors in the globalized world. Each of them will be from the Slovak Republic. As input data will be used their financial statements during years 2015-2018.

\section{Methodology}

Following chapter shows the methodology of the research. Its focused on the data sample $€$ and analysis of the financial performance of six selected enterprises from IT sector in globalized world.

\subsection{Data}

Data sample consist of the six enterprises from IT sector, which represents one of the fastest growing sectors in the globalized world. Each of them will be from the Slovak Republic. As input data will be used their financial statements during years 2015-2018. Table 1 shows their basic characteristics. Enterprises are labelled as E1-6. The data was obtained from Amadeus database - a database of comparable financial information for public and private companies across Europe. 
Table 1. Data characteristic

\begin{tabular}{|c|c|c|c|c|c|}
\hline & Registered office & Number of employees & Legal form & Age of Enterprise & Sales [€] \\
\hline E1 & Žilina & $25-49$ & s. r. o. & 18 & 5032248 \\
\hline E2 & Žilina & $25-49$ & s. r. o. & 21 & 4714202 \\
\hline E3 & Žilina & $25-49$ & s. r. o. & 6 & 4008724 \\
\hline E4 & Žilina & $25-49$ & s. r. o. & 22 & 2036586 \\
\hline E5 & Námestovo & $25-49$ & s. r. o. & 4 & 1588047 \\
\hline E6 & Martin & $25-49$ & s. r. o. & 13 & 1464872 \\
\hline
\end{tabular}

\subsection{Ratios}

The methods of financial-economic analysis will be used to analyse these data. Especially, the paper will be work with selected financial ratios from analysing of liquidity, profitability, indebtedness, and activity. Table 2 show using financial ratios for analysis and comparison the financial performance of selected enterprises under the conditions of globalization $[5,7,8,10,12,15,17,21,22]$

Table 2. Financial ratios

\begin{tabular}{|c|c|}
\hline Ratio & Calculation \\
\hline Cash ratio & (cash/current liabilities) \\
\hline Quick ratio & $\begin{array}{c}\text { (cash }+ \text { short-term receivables)/current } \\
\text { liabilities }\end{array}$ \\
\hline Current ratio & current assets/current liabilities \\
\hline Inventory turnover ratio & inventory/sales $* 365$ \\
\hline Total assets turnover ratio & total assets/sales $* 365$ \\
\hline Average collection period & short-term receivables/sales $* 365$ \\
\hline Return on Assets & EBT/total assets $* 100$ \\
\hline Return on Sales & EAT/sales $* 100$ \\
\hline Return on Equity & EAT/equity $* 100$ \\
\hline Total indebtedness & debt/total liabilities $* 100$ \\
\hline Equity Multiplier & equity/total liabilities *100 \\
\hline
\end{tabular}

\section{Results}

Chapter results provides results of paper research focused on the assessment of the financial health and performance of selected enterprises from IT sector under the conditions of globalized world. 
Table 3. Liquidity ratios

\begin{tabular}{|l|c|c|c|c|c|c|c|c|c|c|c|c|}
\hline & \multicolumn{4}{|c|}{ Cash ratio } & \multicolumn{4}{c|}{ Quick ratio } & \multicolumn{5}{c|}{ Current ratio } \\
\hline Period & \multicolumn{3}{|c|}{ 2018-2015 } & \multicolumn{4}{c|}{ 2018-2015 } & \multicolumn{4}{c|}{ 2018-2015 } \\
\hline E1 & 0.16 & 0.98 & 0.90 & 0.61 & 1.45 & 2.13 & 1.46 & 1.58 & 1.46 & 2.24 & 1.59 & 1.57 \\
\hline E2 & 0.31 & 0.35 & 0.32 & 0.31 & 1.20 & 1.38 & 1.36 & 0.78 & 1.68 & 1.43 & 1.42 & 0.97 \\
\hline E3 & 0.05 & 0.30 & 0.26 & 0.40 & 0.92 & 0.53 & 0.53 & 0.86 & 0.89 & 0.55 & 0.53 & 0.86 \\
\hline E4 & 0.40 & 0.17 & 2.83 & 2.00 & 0.75 & 0.65 & 3.41 & 2.69 & 0.88 & 1.21 & 4.08 & 3.24 \\
\hline E5 & 0.15 & 0.50 & 0.20 & 1.15 & 1.40 & 0.98 & 1.12 & 1.17 & 1.38 & 0.97 & 1.12 & 1.17 \\
\hline E6 & 0.01 & 0.02 & 0.02 & 0.01 & 0.43 & 0.35 & 0.41 & 0.39 & 0.32 & 0.26 & 0.19 & 0.25 \\
\hline
\end{tabular}

Based on the results of cash ratio, we concluded that the most liquid is enterprise 4, which in 2017 reached the value for L1 of 4.08. We consider the least liquid enterprise 6, which in all the monitored years reaches the value of the indicator in the range of 0.01 0.025. As the table shows that most quick liquidity values are in the range of the recommended values of 1 - 1.5, we can conclude that enterprises 1,2,4 and 5 achieve satisfactory values in almost all years. Undertakings 3 and 6 are less satisfactory. The best value of current ratio was again achieved by the enterprise 4. In 2015, the L3 result reached the value of 4.03, which is the highest value. The lowest results were again achieved by the enterprise 6, which, although it has a rising tendency compared to previous years, is still below its satisfactory level. Its resulting value in 2017 was 0.32 , which causes distrust in the solvency of the company.

Table 4. Efficiency ratios

\begin{tabular}{|l|c|c|c|c|c|c|c|c|c|c|c|c|}
\hline & \multicolumn{3}{|c|}{$\begin{array}{c}\text { Inventory turnover } \\
\text { ratio }\end{array}$} & \multicolumn{4}{c|}{ Total assets turnover ratio } & \multicolumn{5}{c|}{ Average collection period } \\
\hline Period & \multicolumn{3}{|c|}{ 2018-2015 } & \multicolumn{4}{c|}{ 2018-2015 } & \multicolumn{4}{c|}{ 2018-2015 } \\
\hline E1 & 7.11 & 15.4 & 10.1 & 222 & 223 & 189 & 7.11 & 15.4 & 109 & 61.3 & 66.4 & 109 \\
\hline E2 & 18.8 & 7.16 & 14.3 & 118 & 174 & 134 & 18.8 & 7.16 & 43.9 & 82.6 & 67.7 & 43.9 \\
\hline E3 & 3.56 & 4.10 & 1.79 & 311 & 394 & 463 & 3.56 & 4.10 & 23.7 & 42.2 & 66.7 & 23.7 \\
\hline E4 & 21.5 & 29.3 & 26.7 & 205 & 202 & 237 & 21.5 & 29.3 & 29.9 & 24.2 & 25.0 & 29.9 \\
\hline E5 & 0.00 & 0.00 & 0.00 & 47 & 48.1 & 31 & 0.00 & 0.00 & 28.8 & 26.7 & 17.1 & 28.8 \\
\hline E6 & 3.60 & 4.91 & 2.63 & 172 & 179 & 133 & 3.60 & 4.91 & 49.0 & 49.4 & 42.0 & 49.0 \\
\hline
\end{tabular}

All monitored enterprises achieve relatively low values in inventory turnover ratio. The most acceptable results are achieved by the enterprise 5 which in all monitored years reaches the zero value of the indicator, which is caused by a very low stock level, that is, they do not have a large amount of funds. On the contrary, the highest value reaches the enterprise 4, where the value of the indicator did not fall below 20, which means that stocks are bound in the enterprise for about 20 days. The total assets turnover ratio shows that the worst value in all years is achieved by the enterprise 3. In 2017 it reached the value of 311.60 , which means that the assets were tied in sales for approximately 311 days. In the period under review, the best time to turnover of total assets was the enterprise 5 , the assets were tied up in sales of approximately 31 days, in other words, the length of the transformation into sales was 31 days. While average collection period in enterprise 2 there was a significant decrease in the value of the indicator from 82.69 days to 43.94 days in 
2017. On the other hand, in enterprise 1 we saw a significant increase from 61.38 days to 109.11 days.

Table 5. Profitability ratios

\begin{tabular}{|l|c|c|c|c|c|c|c|c|c|c|c|c|}
\hline & \multicolumn{4}{|c|}{ Return on Assets } & \multicolumn{4}{c|}{ Return on Sales } & \multicolumn{5}{c|}{ Return on Equity } \\
\hline Period & \multicolumn{3}{|c|}{ 2018-2015 } & \multicolumn{4}{c|}{ 2018-2015 } & \multicolumn{4}{c|}{ 2018-2015 } \\
\hline E1 & 5.9 & 23.7 & 32.4 & 30.43 & 4.02 & 10.58 & 21.1 & 15.6 & 13.2 & 35.2 & 70 & 60.82 \\
\hline E2 & 29 & -4.3 & 33.2 & 43.2 & 10.9 & -1.67 & 13.8 & 15 & 60.8 & -17.2 & 87 & 686 \\
\hline E3 & -14 & -1.5 & -3.3 & -11 & -11 & -1.5 & -4.9 & -16 & -50.9 & -166 & -168 & -149 \\
\hline E4 & 22 & 55. & 25.1 & 31.24 & 17.85 & 21.1 & 18.3 & 19.40 & 44.61 & 84.39 & 30.45 & 38.38 \\
\hline E5 & 31 & -4.2 & 4.03 & 1.41 & 3.11 & -0.8 & 0.47 & 0.23 & 104.6 & 495.8 & 38.13 & 10.19 \\
\hline E6 & 3.6 & 0.1 & 2.26 & -13.8 & 1.47 & 0.05 & 0.88 & -6.50 & 30.60 & 1.48 & 25.42 & -184.0 \\
\hline
\end{tabular}

Based on table 5, we can say that the highest appreciation of total capital was reported by the enterprise 4 in 2016, amounting to almost $56 \%$. The lowest values were reported by the enterprise 3 , which achieved negative results in all monitored years, and the indicator has a decreasing character caused by negative economic result in all monitored years. At the return on sales, the enterprise achieves 3 negative results in 2017 with a value of $11 \%$. This result shows that the enterprise is poorly managed and has high operating costs. Enterprise 4 is at its highest, although it has seen a slight decline but is still in good numbers. In the last reference year, the ability to increase the value of sales resulting from the company's activities is $17 \%$. When evaluating the results of return on equity, we came to the conclusion that the lowest value is again reached by the company 3, which in all years reaches negative values up to $-166.80 \%$ in 2016. In 2017 , the value has already decreased to $-50.98 \%$, which could be due to an increase in equity. The best return on equity indicator in 2017 was reported by the enterprise 5 .

Table 6. Leverage ratios

\begin{tabular}{|l|c|c|c|c|c|c|c|c|}
\hline & \multicolumn{4}{|c|}{ Total indebtedness } & \multicolumn{4}{c|}{ Equity multiplier } \\
\hline Period & \multicolumn{3}{|c|}{ 2018-2015 } & \multicolumn{4}{c|}{ 2018-2015 } \\
\hline E1 & 55.47 & 32.74 & 53.78 & 49.97 & 44.53 & 67.26 & 46.22 & 50.03 \\
\hline E2 & 51.01 & 0.35 & 0.32 & 0.31 & 48.99 & 24.98 & 38.15 & 6.29 \\
\hline E3 & 71.86 & 99.05 & 98.03 & 92.59 & 28.14 & 0.95 & 1.97 & 7.41 \\
\hline E4 & 49.10 & 34.06 & 17.55 & 18.59 & 50.90 & 65.94 & 82.45 & 81.41 \\
\hline E5 & 70.20 & 100.86 & 89.44 & 86.14 & 29.80 & -0.86 & 10.56 & 13.86 \\
\hline E6 & 88.14 & 93.79 & 91.10 & 92.48 & 11.86 & 6.21 & 8.90 & 7.52 \\
\hline
\end{tabular}

In the monitored years, we recorded the lowest total indebtedness in enterprise 4 , which was indebted to approximately $17 \%$ in 2015 , but this value has been increasing in the following years. In 2017 we can be considered the best enterprise 4, which was indebted to $49 \%$. The worst value is again achieved by the enterprise 3 . Although its value in 2017 fell from the original $99 \%$ to $71 \%$, it can still reduce its performance, because foreign capital, although cheaper, is also more risky. One reason for high indebtedness may be the high proportion of short-term liabilities, specifically the value of loans, but also long-term liabilities. The best value in equity multiplier is achieved by the enterprise 4. In 2017 the share of own funds in the total assets of the enterprise was almost $51 \%$ and we can say that 
$€ 1$ of assets is covered by 51 cents of equity. The lowest value is achieved by enterprise 3, which is largely financed by external resources.

\section{Discussion and Conclusion}

The information technology sector is one of the fastest growing sectors. If someone asked why the IT industry was doing well, one of the answers might be that people were interested in technology entry into ever-new areas.

We evaluated the financial health of companies by means of financial-economic indicators. We consider enterprise 2 to be the most successful. Enterprise 1 achieves the unsatisfactory value of the selected criteria and ranked last.

Financial-economic analysis of the company forms an integral part of financial management and occupies an irreplaceable position in the evaluation of the current state or financial health of the company, but also in predicting the financial situation of the company in the future. At the same time, the financial-economic analysis acts as a feedback for the company on whether the financial and economic decisions taken were right, where the company got them, in what areas of financial management he managed to meet the set goals and where on the other hand failed to deliver the expected results. Financialeconomic analysis can not only create a database for making the right decisions in financial management but at the same time reveal the causes of success or failure in previous decisions and the intensity with which these factors have influenced the development to date.

The research leading to these results has received funding from the project titled "Creation of new paradigms of financial management at the threshold of the 21st century in conditions of the Slovak republic" in the frame of the program of Slovak Scientific Grant Agency VEGA under the grant agreement number VEGA 1/0428/17.

\section{References}

1. P. Kral, K. Janoskova, Condition of Acceptability of Project Risk in Management of the Project Portfolio. Proceedings of the 15th International Scientific Conference on Globalization and its Socio-Economic Consequences, Rajecke Teplice, Slovak Republic. 345-352 (2015)

2. V. Bartosova, P. Kral, A Methodological Framework of Financial Analysis Results Objectification in the Slovak Republic. Proceedings of the 3rd International Conference on Business and Economics, Malaysia, European Proceedings of Social and Behavioural Sciences. 17, 189-197 (2016)

3. K. Valaskova, K. Kramarova, B. Kollar, Theoretical Aspects of a model of credit risk determination - Credit risk. Advances in Education Research 81, 401-406 (2015)

4. I Emerling, M. Wojcik-Jurkiewicz, The Risk Associated with the Replacement of Traditional Budget with Performance Budgeting in the Public Finance Sector Management. Ekonomicko-manazerske spektrum 12, 1, 55-63 (2018)

5. E. Ivanova, M. Cepel, The Impact of Innovation Performance on the Competitiveness of the Visegrad 4 Conutries. Journal of Competitiveness 10, 1, 54-72 (2018)

6. M. P. Sponte, Cognitive Performance and Labor Market Outcomes: Evidence from the U.S. Economics, Management, and Financial Markets 13, 2, 70-75 (2018) 
7. M. Dobrodolac, L. Svadlenka, M. Cubranic-Dobrodolac, S. Cicevic, B. Stanivukovic. A Model for the Comparison of Business Units. Personnel Review 47, 1, 150-165 (2018)

8. Csikosova, M. Janoskova, K. Culkova, Prediction of Developments in the Textile and Clothing Industry in Slovakia by Selected Indicators of Financial Analysis. Fibres \& Textiles in Eastern Europe 27, 4, 9-16 (2019)

9. Ozalp, Financial Analysis of Agricultural Development Cooperatives : A Case of Western Mediterranean Region, Turkey. New Medit 18, 2, 119-132 (2019)

10. Y. Chen, L. Duan, Q. Zhang, Financial Analysis of Network Upgrade. Ieee Transactions on Vehicular Technology 67, 6, 5496-5499 (2018)

11. D. Oriskoova, R. Paksiova, Decompositon of ROE to Selected Financial Analysis Indicators. 15th International Scientific Conference of European Financial Systems, Brno, Czech Republic. 479-486 (2018)

12. J. Oscar, K. Knoll, D. Kuvshinov, et al., The Rate of Return on Everything, 18702015. Quarterly Journal of Economics 134, 3, 1225-1298 (2019)

13. Falk, A. Becker, T. Dohmen, et al., Global Evidence on Economic Preferences. Quarterly Journal of Economics 133, 4, 1645-1692 (2018)

14. P. Buckley, M. Casson, Decision-making in International Business. Journal of International Business Studies 50, 8, 1424-1439 (2019)

15. M. Abdi, P. S. Aulakh, Internationalization and Performance: Degree, Duration, and Scale of Operations. Journal of International Business Studies 49, 7, 832-857 (2018)

16. M. Antoni, E. Maug, S. Obernberger, Private Equity and Human Capital Risk. Journal of Financial Economics 133, 3, 634-657 (2019)

17. T. Conley, S. Goncalves, Ch. Hansen, Inference with Dependent Data in Accounting and Finance Applications. Journal of Accounting Research 56, 4, 1139-1203 (2018)

18. P. Liskowsky, M. Minnis, A. Sutherland, Economic Growth and Financial Statement Verification. Journal of Accounting Reserach 55, 4, 745-794 (2017)

19. D. Godsell, M. Welker, N. Zhang, Earnings Management During Antidumpling Investigations in Europe: Sample-Wide and Cross-Sectional Evidence. Journal of Accounting Research 55, 2, 407-457 (2017)

20. J.-N. Barrot, E. Loualiche, J. Sauvagnat, The Globalization Risk Premium. Journal of Finance 74, 5, 2391-2439 (2019)

21. F. Restrepo, L. Cardona-Sosa, P. E. Strahan, Funding Liquidity without Banks : Evidence from a Shock to the Cost of Very Short-Term Debt. Journal of Finance 74, 6, 2875-2914 (2019)

22. J. Bai, D. Carvalho, M. G. Phillips, The Impact of Bank Credit on Labor Reallocation and Aggregate Industry Productivity. Journal of Finance 73, 6, 2787-2836 (2018) 